\title{
PENGARUH MODEL PEMBELAJARAN QUANTUM TEACHING TERHADAP KEMAMPUAN BERPIKIR KREATIF DAN HASIL BELAJAR FISIKA PESERTA DIDIK KELAS XI MIA SMA NEGERI 2 LABUAPI
}

\author{
Nurlaela"), Aris Doyan"1), I Wayan Gunada') \\ 1)Program Studi Pendidikan Fisika, Fakultas Keguruan dan IImu Pendidikan, Universitas Mataram, \\ Mataram, NTB, Indonesia \\ Corresponding author : Nurlaela \\ E-mail : nrella1707@gmail.com
}

Diterima 18 Maret 2021, Direvisi 05 Mei 2021, Disetujui 06 Mei 2021

\begin{abstract}
ABSTRAK
Penelitian ini bertujuan untuk mengetahui pengaruh model pembelajaran Quantum Teaching terhadap kemampuan berpikir kreatif dan hasil belajar fisika peserta didik kelas XI MIA SMAN 2 Labuapi. Jenis penelitian ini merupakan penelitian eksperimen dengan desain post test only control group design. Populasi terdiri dari seluruh peserta didik kelas XI SMAN 2 Labuapi. Teknik pengambilan sampel yang digunakan adalah sampling jenuh, dengan kelas XI MIA 1 sebagai kelas eksperimen dan kelas XI MIA 2 sebagai kelas kontrol. Kelas eksperimen diberi perlakuan dengan menggunakan model pembelajaran quantum teaching dan kelas kontrol diberi perlakuan menggunakan model pembelajaran kovensional. Hipotesis penelitian diuji menggunakan uji manova, hasilnya menunjukkan nilai $\mathrm{F}_{\text {hitung }}>\mathrm{F}_{\text {tabel }}$ dengan $\mathrm{sig}<0,05$ yang artinya $\mathrm{H}_{0}$ ditolak dan $\mathrm{H}_{a}$ diterima, sehingga dapat disimpulkan bahwa terdapat pengaruh model pembelajaran quantum teaching terhadap kemampuan berpikir kreatif dan hasil belajar fisika peserta didik kelas XI MIA SMAN 2 Labuapi.
\end{abstract}

Kata kunci: quantum teaching; kemampuan berpikir kreatif; hasil belajar

\begin{abstract}
The aim of this research is to know the effect of quantum teaching learning model toward the creative thinking skill and physics learning result. The type of research used was experimental with post test only control group design. The population was all student of grade XI in senior high school 2 of Labuapi. The sampling technique used saturation sampling, while the sample are class XI MIA 1 as the experimental class and the XI MIA 2 as control class. Experimental class was treated with quantum teaching learning model and control class was treated with conventional learning model. The research hypothesis was tested using manova-test, analysis shows that $\mathrm{F}_{\text {count }}>\mathrm{F}_{\text {table }}$ with sig $<0,05$ which mean that $\mathrm{H}_{0}$ was rejected and $\mathrm{H}_{\mathrm{a}}$ accepted. Thus, it can be concluded that there are effect of the quantum teaching learning model on student's creative thinking skill and physics learning results of class XI MIA SMAN 2 Labuapi.
\end{abstract}

Keywords: quantum teaching; creative thinking skill; physics learning result

\section{PENDAHULUAN}

Mata pelajaran fisika merupakan salah satu mata pelajaran sains yang dapat mengembangkan kemampuan berpikir analitis deduktif dengan menggunakan berbagai peristiwa alam dan penyelesaian masalah baik secara kualitatif maupun secara kuantitatif dengan menggunakan matematika serta dapat mengembangkan pengetahuan, keterampilan dan sikap percaya diri. Sains pada hakekatnya merupakan sebuah kumpulan pengetahuan, cara atau jalan berpikir, dan cara untuk penyelidikan. Mengingat fisika merupakan bagian dari sains, maka sampai pada tahap ini kita dapat menyamakan persepsi bahwa hakekat fisika adalah sama dengan hakekat IPA atau sains, yakni fisika adalah sebagai produk, fisika sebagai sikap, dan fisika sebagai proses (Hikmawati, 2013).
Kondisi pembelajaran fisika di kelas yang terjadi belakangan ini lebih banyak menempatkan peserta didik sebagai objek yang dapat menerima dan mendengar saja. Pembelajaran fisika masih bergantung pada guru dan buku paket sehingga tidak sesuai dengan upaya untuk mencapai tujuan pendidikan dalam rangka mengelola proses belajar mengajar secara utuh yaitu mengembangkan keterampilan berpikir kreatif, berpikir kritis, berpikir logis, dan berpikir ilmiah peserta didik. Sebab keterampilan berpikir terutama keterampilan berpikir kreatif sangat berpengaruh terhadap perkembangan intelektual peserta didik dan kemampuan peserta didik dalam merasionalisasikan apa yang dipelajarinya. Patut diduga hal ini mengakibatkan pembelajaran fisika menjadi kurang menyenangkan, monoton, membosankan dan dianggap sebagai pelajaran 
yang rumit sehingga kemampuan berpikir kreatif dan hasil belajar fisika peserta didik menjadi rendah.

Mengatasi permasalahan tersebut diperlukan sebuah model pembelajaran yang tepat. Salah satu alternatif model pembelajaran yang dapat digunakan adalah model quantum teaching yakni suatu paket pengajaran yang menyertakan segala energi (kemampuan) untuk memaksimalkan proses belajar (Khaeruman \& Nurhidayati, 2016), karena model pembelajaran ini berpangkal pada psikologi kognitif dan dapat memusatkan perhatian pada interaksi yang bermutu dan bermakna (Hamdayama, 2014). Penggunaan model pembelajaran ini dapat mengubah bermacam-macam interaksi yang ada didalam dan disekitar momen belajar dengan menyingkirkan hambatan yang menghalangi proses belajar alamiah, menyusun bahan pengajaran yang sesuai, cara efektif pembelajaran, dan keterlibatan aktif siswa dan guru (Doyan, 2015). Dengan demikian model pembelajaran ini akan menghidupkan kelas dengan suasana belajar yang menyenangkan serta meningkatkan partisipasi belajar peserta didik. Interaksi antara guru dan peserta didik mampu menumbuhkan pengetahuan baru dan menambah pemahaman peserta didik dalam belajar fisika.

Model pembelajaran quantum teaching memiliki beberapa tahapan dalam pembelajaran yang dapat diimplementasikan pada peserta didik antara lain tumbuhkan, alami, namai, demonstrasikan, ulangi dan rayakan. Penerapan pembelajaran quantum teaching, peserta didik lebih aktif pada pembelajaran yang diajarkan karena dalam proses pembelajaran guru menumbuhkan minat belajar peserta didik dengan memberikan suatu masalah dalam bentuk eksperimen atau dikaitkan dengan kehidupan sehari-hari peserta didik, hal ini dapat membantu peserta didik untuk mengembangkan pengetahuannya secara mendalam, karena peserta didik belajar dengan mengamati sendiri suatu proses melalui suatu percobaan. Peserta didik menyelesaikan masalah dengan mencari informasi yang berkaitan dengan permasalahan secara mandiri, kemudian peserta didik memaparkan gagasan-gagasannya dalam penyelesaian masalah tersebut. Untuk memperkuat atau memperdalam pengetahuan peserta didik, guru memberikan pengulangan dalam bentuk tugas dan untuk mengapresiasi minat belajar peserta didik dalam proses belajar guru memberikan penghargaan.

Selama ini aktivitas pembelajaran di sekolah menengah masih menekankan pada perubahan kemampuan berpikir pada tingkat dasar, belum memaksimalkan kemampuan berpikir tingkat tinggi siswa. Padahal kemampuan berpikir tingkat tinggi juga sangat penting bagi perkembangan mental dan perubahan pola pikir siswa sehingga diharapkan proses pembelajaran dapat berhasil. Salah satu kemampuan berpikir tingkat tinggi yang dapat digunakan untuk menyelesaikan suatu permasalahan adalah keterampilan berpikir kreatif (Purnamaningrum, Dwiastuti, Probosari, \& Noviawati, 2012). Hal tersebut juga terjadi pada pembelajaran fisika sesuai dengan pernyataan dari (Nisa \& Wasis, 2013), bahwa pembelajaran Fisika selama ini kurang memberikan perhatian terhadap pengembangan kemampuan berpikir tingkat tinggi seperti kemampuan berpikir kreatif. Padahal, kemampuan ini sangat penting, karena dalam kehidupan sehari-hari setiap orang selalu dihadapkan pada berbagai masalah yang harus dipecahkan dan menuntut pemikiran kreatif untuk menemukan solusi dari permasalahan yang dihadapi. Pentingnya kemampuan berpikir kreatif ditegaskan dalam Permendiknas No.23 Tahun 2006 tentang Standar Kompetensi Lulusan (SKL) untuk Satuan Pendidikan Dasar dan Menengah yang menyebutkan bahwa salah satu tujuan satuan pendidikan adalah membangun dan menerapkan informasi dan pengetahuan secara logis, kritis, kreatif, dan inovatif.

Berpikir kreatif adalah penggunaan dasar proses berpikir untuk mengembangkan atau menemukan ide atau hasil yang asli (orisinil), estetis, konstruktif yang berhubungan dengan pandangan, konsep, yang penekanannya ada pada aspek berpikir intuitif dan rasional khususnya dalam menggunakan informasi dan bahan untuk memunculkan atau menjelaskannya dengan perspektif asli pemikir (Arnyana, 2006). Kemampuan berpikir kreatif siswa tidak dapat berkembang dengan baik apabila dalam proses pembelajaran guru tidak melibatkan siswa secara aktif dalam pembentukan konsep, metode pembelajaran yang digunakan di sekolah masih secara konvensional, yaitu pembelajaran yang masih berpusat pada guru. Pembelajaran tersebut dapat menghambat perkembangan kreatifitas dan aktifitas siswa seperti dalam hal mengkomunikasikan ide dan gagasan. Sehingga keadaan ini tidak lagi sesuai dengan target dan tujuan pembelajaran matematika. Tujuan pembelajaran akan tercapai apabila perencanaan dan metode yang digunakan dapat mempengaruhi potensi dan kemampuan yang dimiliki peserta didik dan keberhasilan tersebut akan tercapai apabila peserta didik dilibatkan dalam proses berpikirnya (Sugilar, 2013).

Kemampuan berpikir kreatif memiliki indikator (Sunaryo, 2014) yakni sebagai berikut:

a. Kefasihan adalah kemampuan dalam mengajukan sejumlah masalah atau pertanyaan matematika dan jawaban yang tepat. 
b. Keluwesan adalah kemampuan menghasilkan jawaban yang bervariasi/beragam/beberapa cara.

c. Keaslian/hal yang relatif baru adalah kemampuan memberikan gagasan atau jawaban dengan bahasa dan cara sendiri.

d. Keterperincian/elaborasi adalah kemampuan menjelaskan, mengembangkan, memperkaya atau menguraikan lebih rinci jawaban atau gagasan yang diberikan.

\section{METODE PENELITIAN}

Jenis penelitian yang digunakan adalah eksperimen, dimana penelitian digunakan untuk mencari pengaruh perlakuan tertentu terhadap variabel-variabel yang diteliti dan dalam kondisi yang dikendalikan (Sugiyono, 2013). Desain penelitian yang digunakan adalah post test only control group. Desain penelitian ini menggunakan dua kelompok subjek yaitu kelas eksperimen dan kelas kontrol. Tidak ada pretest yang diberikan kepada kedua kelompok. Desain ini bertujuan untuk melakukan analisis data dari desain penelitian ini dilakukan perbandingan skor ratarata antara $\mathrm{O}_{1}$ dan $\mathrm{O}_{2}$ (Setyosari, 2015). Desain penelitian ini dapat dilihat dalam Tabel 1.

Tabel 1. Desain Penelitian Post test Only Control Group Design

\begin{tabular}{cccc}
\hline $\mathrm{R}$ & $\mathrm{X}$ & $\mathrm{O}_{1}$ & (Kelompok eksperimen) \\
\hline $\mathrm{R}$ & $\mathrm{O}_{2}$ & (Kelompok kontrol) \\
\hline
\end{tabular}

Populasi dalam penelitian adalah semua peserta didik kelas XI MIA sebanyak 39 peserta didik yang terbagi dalam dua kelas. Teknik pengambilan sampel menggunakan sampling jenuh karena seluruh populasi digunakan sebagai sampel sehingga terpilihlah kelas XI MIA 1 sebagai kelas eksperimen dan kelas XI MIA 2 sebagai kelas kontrol. Instrumen kemampuan berpikir kreatif dan hasil belajar peserta didik diukur menggunakan instrumen tes berupa soal uraian sebanyak 5 pertanyaan untuk kemampuan berpikir kreatif sedangkan hasil belajar berupa soal pilihan ganda sebanyak 25 pertanyaan.

Instrumen tes diuji dengan uji validitas butir soal, uji reliabilitas, uji tingkat kesukaran soal, dan uji daya beda soal. Prasyarat analisis data menggunakan uji yaitu uji homogenitas matriks varian-kovarian dan uji hipotesis menggunakan uji manova dengan bantuan SPSS 18.

Uji hipotesis dilakukan untuk mengetahui perbedaan kemampuan berpikir kreatif dan hasil belajar fisika peserta didik pada kedua kelas setelah diberi perlakuan.

\section{HASIL DAN PEMBAHASAN}

Tujuan penelitian ini adalah untuk mengetahui pengaruh model pembelajaran Quantum Teaching terhadap kemampuan berpikir kreatif dan hasil belajar fisika peserta didik. Data penelitian berupa data kemampuan berpikir kreatif dan data hasil belajar yang didapat dari nilai posttest.

\section{Kemampuan Berpikir Kreatif}

Adapun data kemampuan berpikir kreatif dari kedua kelas disajikan pada gambar 1 dan 2 berikut.

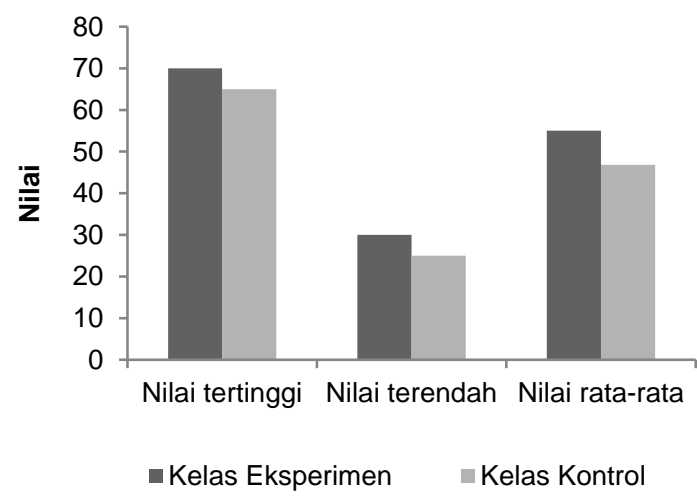

Gambar 1. Nilai Kemampuan Berpikir Kreatif Peserta Didik

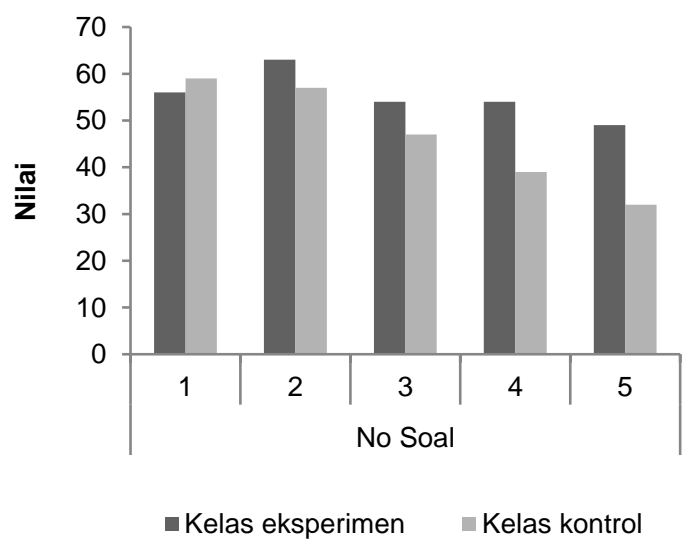

Gambar 2. Nilai Kemampan Berpikir Kreatif Peserta Didik Tiap Item Soal

Data kemampuan berpikir kreatif peserta didik memperlihatkan bahwa nilai pada kelas eksperimen lebih tinggi daripada nilai peserta didik di kelas kontrol. Datanya dapat dilihat pada tabel 2. 
Tabel 2. Hasil Tes Akhir Kemampuan Berpikir Kreatif Peserta Didik Kelas Eksperimen dan Kelas Kontrol

\begin{tabular}{llll}
\hline Kelas & $\begin{array}{l}\text { Jumlah } \\
\text { Peserta } \\
\text { Didik }\end{array}$ & $\begin{array}{l}\text { Rata- } \\
\text { rata }\end{array}$ & Kategori \\
\hline Eksperimen & 20 & 55,00 & $\begin{array}{l}\text { Cukup } \\
\text { Kreatif } \\
\text { Cukup } \\
\text { Kreatif }\end{array}$ \\
\hline
\end{tabular}

Perbedaan rata-rata nilai antara keduanya yang signifikan menunjukkan bahwa peserta didik pada kelas eksperimen sudah lebih mampu dalam menyelesaikan persoalan yang berkaitan dengan persamaan atau rumus-rumus serta mampu membuat alternatif jawaban baru maupun cara penyelesaian atau membuat masalah yang berbeda dengan lancar (fasih), fleksibel dan terperinci dibandingkan dengan kelas kontrol. Penerapan model pembelajaran quantum teaching merangsang peserta didik untuk lebih aktif dalam mengikuti kegiatan belajar mengajar dan suasana kelas menjadi lebih hidup serta peserta didik lebih bersemangat dalam mengikuti proses pembelajaran di kelas. Proses pembelajaran peserta didik bukan hanya dituntut sekedar mendengar dan mencatat, akan tetapi menghendaki aktivitas peserta didik dalam proses berpikir terutama berpikir kreatif. Nilai kemampuan berpikir kreatif peserta didik pada kelas eksperimen juga lebih tinggi dari kelas kontrol dalam setiap item soal yang digunakan. Datanya dapat dilihat pada tabel 3 .

Tabel 3. Deskripsi Nilai Tiap Item Soal Tes Kemampuan Berpikir Kreatif Peserta Didik Kelas Eksperimen dan Kelas Kontrol

\begin{tabular}{|c|c|c|c|c|c|c|}
\hline \multirow[b]{2}{*}{ Indikator } & \multicolumn{3}{|c|}{ Kelas Eksperimen } & \multirow[b]{2}{*}{$\begin{array}{l}\text { Skor } \\
\text { Total }\end{array}$} & \multicolumn{2}{|c|}{ Kelas Kontrol } \\
\hline & $\begin{array}{l}\text { Skor } \\
\text { Total }\end{array}$ & Nilai & Kategori & & Nilai & Kategori \\
\hline Kelancaran & 45 & 56 & $\begin{array}{l}\text { Cukup } \\
\text { Kreatif }\end{array}$ & 45 & 59 & $\begin{array}{l}\text { Cukup } \\
\text { Kreatif }\end{array}$ \\
\hline Keluwesan & 50 & 63 & Kreatif & 43 & 57 & $\begin{array}{l}\text { Cukup } \\
\text { Kreatif }\end{array}$ \\
\hline Keaslian & 43 & 54 & $\begin{array}{l}\text { Cukup } \\
\text { Kreatif }\end{array}$ & 36 & 47 & $\begin{array}{l}\text { Cukup } \\
\text { Kreatif }\end{array}$ \\
\hline Keterperincian & 43 & 54 & $\begin{array}{l}\text { Cukup } \\
\text { Kreatif }\end{array}$ & 30 & 39 & $\begin{array}{l}\text { Kurang } \\
\text { Kreatif }\end{array}$ \\
\hline Keterperincian & 39 & 49 & $\begin{array}{l}\text { Cukup } \\
\text { Kreatif }\end{array}$ & 24 & 32 & $\begin{array}{l}\text { Kurang } \\
\text { Kreatif }\end{array}$ \\
\hline
\end{tabular}

Data tersebut memperlihatkan bahwa nilai tertinggi terdapat pada item soal kedua indiaktor kedua yaitu berpikir luwes. Nilai tertinggi pada indikator tersebut menandakan bahwa dengan model pembelajaran quantum teaching yang diterapkan pada kelas eksperimen menyebabkan informasi atau pengetahuan yang didapatkan peserta didik saat diberikan suatu masalah biasanya memikirkan bermacam cara yang berbeda untuk menyelesaikannya (berpikir secara fleksibel) dan arah pemikirannya berbeda dengan kelas kontrol, karena pada kelas kontrol untuk menyelesaikan masalah terlebih dahulu diberikan umpan terlebih oleh guru.

\section{Hasil Belajar}

Adapun data hasil belajar pada kelas eksperimen dan kelas kontrol disajikan pada gambar 3 berikut.

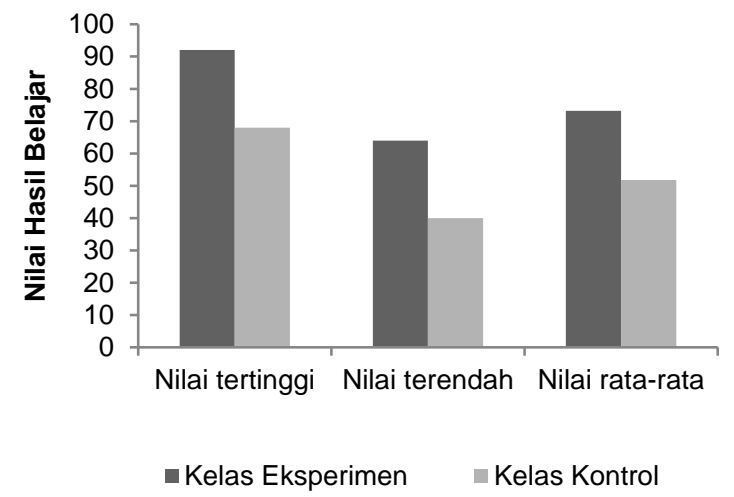

Gambar 3. Data Hasil Belajar

Nilai kemampuan berpikir kreatif peserta didik pada kelas eksperimen yang lebih tinggi dari peserta didik di kelas kontrol juga berdampak pada hasil belajar peserta didik. Datanya dapat dilihat pada tabel 4 .

Tabel 4. Nilai Hasil Belajar Peserta Didik Kelas Eksperimen dan Kelas Kontrol

\begin{tabular}{ccc}
\hline Kelas & $\begin{array}{c}\text { Jumlah } \\
\text { Peserta Didik }\end{array}$ & Rata-rata \\
\hline Eksperimen & 20 & 73,20 \\
Kontrol & 19 & 51,79 \\
\hline
\end{tabular}

Hal ini menunjukkan bahwa model pembelajaran yang diterapkan tidak hanya berpengaruh pada kemampuan berpikir kreatif tetapi juga berpengaruh pada hasil belajar, sesuai dengan penelitian (Mohiddin, 2016) yang menyatakan bahwa pada peserta didik yang diterapkan model pembelajaran quantum teaching dalam pemecahan masalah matematis memiliki kemampuan berpikir kreatif lebih tinggi dibandingkan peserta didik yang diterapkan model pembelajaran konvensional, sehingga hal tersebut juga berpengaruh pada hasil belajar peserta didik.

Kemampuan berpikir kreatif siswa tidak dapat berkembang dengan baik apabila dalam proses pembelajaran guru tidak melibatkan peserta didik secara aktif dalam pembentukan konsep, metode pembelajaran yang digunakan di sekolah masih secara konvensional, yaitu pembelajaran yang masih berpusat pada guru. 
Pembelajaran tersebut dapat menghambat perkembangan kreatifitas dan aktifitas siswa seperti dalam hal mengkomunikasikan ide dan gagasan. Sehingga keadaan ini tidak lagi sesuai dengan target dan tujuan pembelajaran yakni meningkatkan hasil belajar peserta didik sesuai dengan pernyataan (Khaeruman \& Nurhidayati, 2016), hasil belajar yang dicapai oleh para pelajar menggambarkan hasil usaha yang dilakukan oleh guru dalam memfasilitasi dan menciptakan kondisi kegiatan belajar mereka. Model pembelajaran quantum teaching menekankan peserta didik untuk belajar dalam kelompok-kelompok. Melalui kelompok ini peserta didik dapat berdiskusi tentang masalah yang diberikan dengan saling bertukar ide. Peserta didik yang lebih pandai dapat memberikan masukan bagi teman satu kelompoknya, membantu teman yang belum paham sehingga peserta didik yang pengetahuannya tentang pelajaran masih kurang dapat termotivasi dalam belajar. Motivasi yang kuat memberikan dampak yang positif terhadap hasil belajar untuk mencapai ketuntasan belajar. Cara belajar kelompok adalah suatu cara pendekatan yang khusus dirancang untuk memberikan dorongan kepada peserta didik agar bekerjasama selama pembelajaran berlangsung, yang tentunya dapat meningkatkan pemahaman peserta didik. Dengan ini dapat memunculkan interaksi yang kuat antara peserta didik dengan peserta didik, maupun antara peserta didik dengan guru sebagai pembimbing dalam proses pembelajaran sehingga dapat meningkatkan hasil belajar fisika peserta didik. Beberapa alasan mengapa nilai hasil belajar fisika peserta didik yang diajar dengan model Quantum Teaching lebih tinggi dibandingkan dengan hasil belajar peserta didik yang diajar dengan model pembelajaran konvensional adalah karena model pembelajaran Quantum Teaching membuat peserta didik lebih bersemangat dalam belajar, karena peserta didik mendapatkan pengalaman langsung tentang materi yang dipelajarinya, sehingga materi akan lebih berkesan dan akan tersimpan lama dalam memori jangka panjang, yang pada akhirnya akan mempengaruhi ketuntasan belajar peserta didik.

Faktor yang mempengaruhi ketuntasan belajar peserta didik, diantaranya adalah peran guru dalam menyampaikan pembelajaran, teknik diskusi atau model pembelajaran, dan waktu yang tersedia untuk belajar. Keberhasilan peserta didik dalam belajar dapat dilihat dari kemampuan peserta didik dalam menguasai materi pelajaran yang diberikan termasuk pada kemampuan peserta didik dalam berpikir kreatif. Berpikir kreatif diasumsikan secara umum sebagai proses kognitif yaitu suatu aktivitas mental yang lebih menekankan penalaran untuk memperoleh pengetahuan, hal ini dapat dilihat dengan adanya perubahan tingkah laku dalam diri peserta didik setelah terjadi proses pembelajaran.

Pembelajaran fisika akan lebih maksimal jika pembelajaran dilakukan secara bermakna dan mengoptimalkan kegiatan yang dapat meningkatkan kemampuan berpikir kreatif dan hasil belajar peserta didik dalam proses pembelajaran di kelas. Tercapainya hal yang demikian, diperlukannya pemilihan model pembelajaran yang sesuai dengan karakteristik materi yang diajarkan pada peserta didik serta penggunaan bahan ajar yang menunjang kegiatan pembelajaran.

\section{SIMPULAN DAN SARAN}

Terdapat pengaruh model pembelajaran quantum teaching terhadap kemampuan berpikir kreatif dan hasil belajar fisika peserta didik SMAN 2 Labuapi. Pengaruh ini berupa tingkat kemampuan berpikir kreatif dan hasil belajar fisika peserta didik di kelas eksperimen lebih tinggi dibandingkan peserta didik pada kelas kontrol.

Hendaknya masalah dan fenomena yang diangkat sebagai apersepsi harus sesuai dengan pengetahuan dan pengalaman peserta didik, mempersiapkan semua perangkat pembelajaran yang dibutuhkan dengan memperhatikan alokasi waktu pembelajaran, menyiapkan/mengecek alat dan bahan yang diperlukan sebaik mungkin. Untuk mengukur hasil belajar peserta didik sebaiknya mengkolaborasikan soal pilihan ganda dengan soal uraian sehingga bisa meminimalisir peluang peserta didik menebak jawaban, selanjutnya lebih diperhatikan kembali tata ruang, lokasi tempat duduk, dan dilakukan pengawasan lebih ketat agar tidak terjadi kerja sama antar peserta didik dalam menyelesaikan tes yang diberikan.

\section{UCAPAN TERIMA KASIH}

Terima kasih yang sebesar-besarnya penulis sampaikan kepada Bapak Aris Doyan, M.Si., Ph.D., selaku dosen pembimbing I dan Bapak I Wayan Gunada, S.Si., M.Pd., selaku dosen pembimbing II yang selalu sabar dan ikhlas dalam membimbing penulis hingga penulisan skripsi ini selesai dan terimakasih juga kepada Bapak Drs. Sutrio, M.Si., selaku dosen penguji yang telah memberikan saran dan masukan dalam penulisan skripsi ini.

\section{DAFTAR RUJUKAN}

Arnyana, I. B. (2006). Pengaruh Penerapan Strategi Pembelajaran Inovatif pada Pelajaran Biologi Terhadap Kemampuan Berpikir Kreatif Siswa SMA. Jurnal Pendidikan dan Pengajaran IKIP Negeri Singaraja, 3(6), 496-515.

Doyan, A. (2015). Penerapan Model Pembelajaran Kuantum pada Matakuliah Fisika Kuantum 
Ditinjau dari Motivasi Berprestasi. Jurnal Pendidikan Fisika dan Teknologi, 1(1), 1-8. Hamdayama, J. (2014). Model dan Metode Pembelajaran Kreatif dan Berkarakter. Jakarta: Ghalia Indonesia.

Hikmawati. (2013). Kajian Fisika SMA. MataramFKIP Press.

Khaeruman, \& Nurhidayati, S. (2016). Trik-Trik Mengajar. Mataram: LPP Mandala.

Mohiddin, D. P. (2016). Pengaruh Model Pembelajaran Quantum Teaching dan Kemampuan Berpikir Matematis Terhadap Hail Belajar Siswa. Jtech, 4(2), 90-93.

Nisa, K., \& Wasis. (2013). Pengaruh Pendekatan Open-Ended Terhadap Kemampuan Berpikir Kreatif Siswa pada Materi Listrik Dinamis Kelas $X$ di SMAN 1 Gondang Tulungagung. Jurnal Inovasi Pendidikan Fisika, 2(3), 143-146.

Purnamaningrum, A., Dwiastuti, S., Probosari, R. M., \& Noviawati. (2012). Peningkatan Kemampuan Berpikir Kreatif melalui Problem Based Learning (PBL) pada Pembelajaran Biologi Kelas X-10 SMA Negeri 3 Surakarta Tahun Pelajaran 2011/2012. Jurnal Pendidikan Biologi, 4(3), 39-51.

Setyosari, P. (2015). Metode Penelitian Pendidikan dan Pengembangan. Malang: Prenadamedia Group.

Sugilar, H. (2013). Meningkatkan Kemampuan Berpikir Kreatif dan Disposisi Matematik Siswa Madrasah Tsanawiyah Melalui Pembelajaran Generatif. Jurnal IImiah Program Studi Matematika STKIP Siliwangi Bandung, 2(2), 156-168.

Sugiyono. (2013). Metode Penelitian Pendidikan : Pendekatan Kuantitatif, Kualitatif, dan $R \& D$. Bandung: Alfabeta.

Sunaryo, Y. (2014). Model Pembelajaran Berbasis Masalah untuk Meningkatkan Kemampuan Berpikir Kritis dan Kreatif Matematik Siswa SMA di Kota Tasikmalaya. Jurnal Pendidikan dan Keguruan, 1(2), 41-51. 